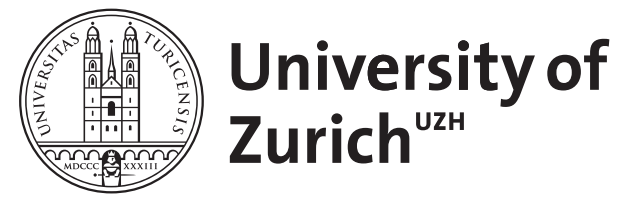

\title{
Nanoscale bioactive glass activates osteoclastic differentiation of RAW 264.7
} cells

Detsch, Rainer ; Rübner, Matthias ; Strissel, Pamela L ; Mohn, Dirk ; Strasser, Erwin ; Stark, Wendelin J ; Strick, Reiner ; Boccaccini, Aldo R

DOI: https://doi.org/10.2217/nnm.16.20

Posted at the Zurich Open Repository and Archive, University of Zurich ZORA URL: https://doi.org/10.5167/uzh-128437

Journal Article

Accepted Version

Originally published at:

Detsch, Rainer; Rübner, Matthias; Strissel, Pamela L; Mohn, Dirk; Strasser, Erwin; Stark, Wendelin J; Strick, Reiner; Boccaccini, Aldo R (2016). Nanoscale bioactive glass activates osteoclastic differentiation of RAW 264.7 cells. Nanomedicine, 11(9):1093-1105.

DOI: https://doi.org/10.2217/nnm.16.20 


\section{Nanoscaled bioactive glass activates osteoclastic differentiation of RAW 264.7 cells}

Rainer Detsch ${ }^{1^{*}}$, Matthias Rübner $^{2}$, Pamela L. Strissel $^{2}$, Dirk Mohn ${ }^{3,4}$, Erwin Strasser $^{5}$, Wendelin J. Stark ${ }^{3}$, Reiner Strick ${ }^{2}$ and Aldo R. Boccaccini ${ }^{{ }^{*}}$

${ }^{1}$ Department of Materials Science and Engineering, Institute of Biomaterials, University of Erlangen-Nuremberg, Cauerstraße 6, 91058 Erlangen, Germany

${ }^{2}$ Department of Gynaecology and Obstetrics, Laboratory for Molecular Medicine, FriedrichAlexander University Erlangen-Nürnberg (FAU),University-Clinic Erlangen,

Universitätsstraße 21-23, 91054 Erlangen, Germany

${ }^{3}$ Institute for Chemical and Bioengineering, ETH Zurich, Wolfgang-Pauli-Straße. 10, 8093 Zurich, Switzerland

${ }^{4}$ Department of Preventive Dentistry, Periodontology, and Cariology, University of Zurich Center for Dental Medicine, Plattenstraße. 11, 8032 Zurich, Switzerland

${ }^{5}$ Department of Transfusion Medicine and Haemostaseology, University-Clinic Erlangen, Krankenhausstraße 12, 91054 Erlangen, Germany

Corresponding authors*:

rainer.detsch@fau.de

aldo.boccaccini@ww.uni-erlangen.de

Abstract (215 words)

Key words: osteoclasts; biomaterials; $45 \mathrm{~S} 5$ nanoscaled (n) Bioactive glass (BG) 


\begin{abstract}
Presently, there is limited knowledge regarding the differentiation of osteoclasts in the presence of nanoscale bioactive glasses $(\mathrm{nBG})$. This investigation examined increasing concentrations of $45 \mathrm{~S} 5 \mathrm{nBG}$ and its influence on osteoclast differentiation. After 14 days of culturing cells with $500 \mu \mathrm{g} / \mathrm{ml} \mathrm{nBG}$ viability of $\sim 100 \%$ was detected, however DNA synthesis was reduced supporting the differentiation into osteoclast-like cells. RNA activation of nine genes occurred in a nBG concentration dependent manner. Low concentrations of nBG increased expression of genes involved in commitment to cell fusion. High concentration of nBG increased gene expression supporting osteoclast-like differentiation. We conclude that nBG enhances RAW 264.7 osteoclast differentiation especially controlling gene expression in a concentration dependent manner, which could reflect normal regulation during bone growth.
\end{abstract}

Background: There is limited knowledge regarding differentiation of osteoclasts in the presence of nanoscale bioactive glasses $(\mathrm{nBG})$. This investigation examined increasing concentrations of $45 \mathrm{~S} 5 \mathrm{nBG}$ and its influence on osteoclast differentiation.

Materials and Methods: Different concentrations of $45 \mathrm{~S} 5 \mathrm{nBG}$ were cultured up to 14 days with the murine RAW264.7 cell line and human primary monocytes and M-CSF and RANKL.

Results: Culturing cells for 14 days with $500 \mu \mathrm{g} / \mathrm{ml} \mathrm{nBG}$ showed a viability of $100 \%$; however DNA synthesis was reduced, supporting differentiation into osteoclast-like cells. Using RAW cells, activation of nine genes, including cell fusion genes, occurred in an nBG concentration dependent manner. Low concentrations of $\mathrm{nBG}$ increased expression of genes involved in commitment to cell fusion, whereas high concentrations increased gene expression supporting osteoclast-like differentiation.

Conclusion: nBG enhances both RAW264.7 and human osteoclast differentiation. nBG controlled gene expression in a concentration dependent manner could reflect normal regulation during bone growth. 


\section{Introduction}

World-wide there are more than 2 million cases per year involving patients needing bonegrafts for dental or orthopaedic procedures due to bone injuries and disease complications like tumor destruction of bone [1]. In light of the fact that bone has a healing capacity through bone remodeling in response to injury or tumor destruction, the limiting factor for regeneration is linked not only with the individual's age but also with the amount of bone loss or damage. Despite the possibility of using auto-, allo- or xenografts for bone replacement there are clinical risks including graft availability, infection, reduced mechanical movement, a poorly functioning graft or graft rejection [2]. Bone tissue engineering represents an alternative to current approaches with ultimate goal being the combination of progenitor cells with growth factors and biomaterial substrates to form a three-dimensional (3D) structure that supports new bone formation [3-5]. An assortment of materials such as calcium carbonate, hydroxyapatite (HAp), bioactive glasses (BG) like 45S5 BG, tricalcium phosphate (TCP), biphasic ceramics of HAp and $\alpha$ - or $\beta$-TCP, biopolymers and numerous biodegradable polymer-ceramic composites are of great interest for the development of bone substitutes in bone repairing and reconstruction [2,6,7]. Nevertheless, bone regeneration is a complex process that involves the coordination of a variety of different cascades and can be typically characterized by initial inflammatory response, followed by bone formation, vascularization and bone remodeling [8]. From the beginning, osteoclasts are fundamentally engaged in the whole interactive process, but, interestingly, there is a lack of research of osteoclast interaction with bone substitutes. Important parameters determining osteoclast differentiation and bone resorption activity with biomaterial bone substrates are material composition, roughness, crystal grain size and surface energy and wettability, as reviewed elsewhere [2]. A few in vitro cell culture studies using a variety of cell types e.g. U-937 and RAW 264.7 monocytic-macrophage leukemia cells, fibroblasts, endothelial cells and primary osteoclast progenitors have been carried out with several of the above bone substitute materials to not only assess osteoclast differentiation and osteoclast activity but also secretion of cellular factors [2]. Specifically, the RAW 264.7 murine leukemia cell line has been used as an important in vitro cell culture model for studying activation and differentiation into osteoclastlike cells $[9,10]$. For example, when RAW 264.7 cells were grown for 14 days on HAp and stimulated with RANKL, differentiation via cell fusion occurred into osteoclast-like multinucleated cells [9]. Additionally, 3D cell culture scaffolds composed of biphasic calcium phosphate (BCP) biomaterial, human plasma clots, and RAW 264.7 cells stimulated for 2 days in the presence of a transfected overexpression vector containing a glutathione-S transferase (GST)-RANKL fusion protein demonstrated significantly increased expression of 
Vegfa and Vegfc compared to untreated controls [11]. When RAW 264.7 cells were cultured in the presence of 3D printed scaffold surfaces, composed of pure HA and $\beta$-TCP or a biphasic mixture of HA and TCP (60:40), cellular proliferation and differentiation into TRAP $5 \mathrm{~b}$ positive stained osteoclast-like cells with resorbing activity occurred [12]. Importantly, an increase of osteoclastic specific genes with expression of various markers (e.g. integrin $\beta 3$, integrin $\alpha v, C A$ isoform II, RANK, cathepsin $K$ ) was also found, thus supporting ceramic substances as effective bone substitutes.

Despite the complexities of osteoclast biology, the cellular process of bone resorption has been successfully mimicked in vitro using different bone substitutes in tissue-engineering approaches in order to understand how osteoclast development occurs and the influences that different substrates have on this process [13-16]. There is a need for better clinical options for the patient regarding bio-engineered bone substitutes, which not only support bone regeneration but, at the same time degrade at a suitable rate. One important biomaterial being considered in bone regeneration approaches is bioactive glass [17], in particular $45 \mathrm{~S} 5 \mathrm{BG}$ of the composition (wt\%) $45 \% \mathrm{SiO}_{2}, 24.5 \% \mathrm{Na}_{2} \mathrm{O}, 24.5 \% \mathrm{CaO}$, and $6 \%$ $\mathrm{P}_{2} \mathrm{O}_{5}$, including its variant in nanoparticle morphology [18]. Presently, to our knowledge, there are no studies regarding the differentiation and behavior of osteoclasts in the presence of nanoscaled ( $n$ ) $45 S 5$ bioactive glass (BG), despite the fact that this material has shown enhanced bioactivity in vitro [19] and has been available for the last 10 years [20]. In a continuing search for compatible bone substitutes this investigation examined for the first time 45S5 nBG and its influence on osteoclast differentiation, osteoclast activity, cytokine and growth factor production using the RAW 264.7 murine monocytic-macrophage leukemia cell line.

\section{Materials and Methods}

\subsection{Bioactive glass}

Nanoscaled bioactive glass ( $\mathrm{nBG}$ ) particles of nominal composition (in wt\%): $47.8 \% \mathrm{SiO}_{2}$, $25.1 \% \mathrm{CaO}, 22.6 \% \mathrm{Na}_{2} \mathrm{O}$ and $4.6 \% \mathrm{P}_{2} \mathrm{O}_{5}$, were synthesized by means of flame spray synthesis, as described elsewhere [20]. Using high temperature synthesis results in a relatively homogenous amorphous material with controllable particle size and surface area. Briefly, synthesis was performed by combining and mixing the corresponding liquid metal precursors with anion precursors and then feeding the mixture into a flame reactor. The resulting nanopowder was collected on a filter mounted above the flame. The specific surface area of the obtained $\mathrm{nBG}$ was $60-80 \mathrm{~m}^{2} \mathrm{~g}^{-1}$, while the particle size ranges between $20-60 \mathrm{~nm}$. Sterilization was performed by dry heat at $160{ }^{\circ} \mathrm{C}$ during $7 \mathrm{~h}$ in a furnace (B180, Nabertherm, Germany). For cell culture experiments the $45 \mathrm{~S} 5 \mathrm{nBG}$ was added directly into the cell growth medium. 


\subsection{Cell culture}

For cell culture experiments we used the RAW 264.7 cell line, a mouse leukaemic monocyte-macrophage cell line established from an ascites derived from intraperitoneal injection of the Abselon murine leukaemia virus (AMuLV) into a male mouse. In 48-well plates $1 \times 10^{5}$ RAW 264.7 cells were cultured in alpha-Minimal Essential Medium (Gibco, Germany) containing fetal calf serum (10\%) in a final volume of $600 \mu \mathrm{l}$ for 14 days. Additionally, the used differentiation media (DM) were supplemented with macrophage colony-stimulating factor (murine M-CSF, $25 \mathrm{ng} \cdot \mathrm{ml}-1$, Biochrom, Germany) and the receptor activator of the NF kappa-B ligand (murine RANKL, $40 \mathrm{ng} \mathrm{ml}-1$, Biochrom, Germany).

\subsection{Cell proliferation and viability}

After an incubation period of 14 days, RAW 267.4 cells were analyzed for cell proliferation by quantifying the amount of DNA synthesis and cell viability by assessing mitochondrial activity. The 5-bromo-2'-deoxyuridine (BrdU) assay (Roche, Germany) is based on the detection of BrdU incorporation into genomic DNA of proliferating cells. Following incorporation, BrdU was then colorimetrically detected by an ELISA reader (Phomo, Anthos Mikrosysteme $\mathrm{GmbH}$, Germany). The mitochondrial activity of cytokine stimulated RAW 267.4 cells was measured for absorbance at $450 \mathrm{~nm}$ in a 96 well plate following the conversion of tetrazolium (WST-1, Roche, Germany) to formazan by endogenous mitochondrial enzymes. In parallel, using phase contrast microscopy (Axiovert, Zeiss, Germany) an analysis was performed to address the overall cellular phenotype.

\subsection{RNA extraction and cDNA synthesis}

Total RNA was extracted from cells according to previously published methods [21]. After RNA was pre-treated with DNasel (Roche, Germany) cDNA was generated with the High Capacity cDNA kit (Applied Biosystems, Germany) at $37^{\circ} \mathrm{C}$ in a thermal cycler for $2 \mathrm{~h}$. Semiquantitative real time PCR (sqPCR) with SYBR-green was performed with specific primers for Ctsk, Trap5, Car2, Vegfa, Rank-I, Ror-2, Syncytin-A and Syncytin-B (Supple.Tab.1). Coamplification of 18SrRNA and one control cDNA was used as internal control and for the $2^{-}$ ${ }_{\triangle \Lambda}^{\mathrm{CT}}$ calculation.

\subsection{Imaging}

TRAP5 staining: Cell morphology and TRAP5-staining were imaged using bright field microscopy (Axiovert, Zeiss, Germany). The formation of tartrate resistant acid phosphatase (TRAP5)-positive cells was determined by using a commercially available kit (Sigma, Germany). Cells were fixed and stained after 14 days of cultivation, then examined using 
light microscopy (Axiovert, Zeiss, Germany), where TRAP-positive cells were a maroon color.

Cellular cytoskeleton and $n B G$ mineral detection: To observe the formation of the cytoskeleton 'actin ring', the cell distribution and the mineralization process occurring with the $45 S 5$ nBG particles we used fluorescence microscopy (FM, Scope.A1, Carl Zeiss, Germany) and confocal scanning laser microscopy (CSLM, Leica TCS SP5 II, Germany). After 14 days of cultivation, adherent cells were fixed with $3.7 \%$ paraformaldehyde for $10 \mathrm{~min}$ and then permeabilized with 0.1 vol. $\%$ Triton X-100 (in PBS) for 10min RT. The fluorescent red-range Alexa Fluor ${ }^{\circledR}$ Phalloidin actin binding compound (Molecular Probes ${ }^{\circledR}$, Germany) $(679 \mathrm{~nm}$ excitation and $702 \mathrm{~nm}$ emission) was used to detect the cytoskeleton. The fluorescent bluerange DNA binding compound, DAPI (4',6-diamidino-2-phenylindoledihydrochloride; $350 \mathrm{~nm}$ excitation and $465 \mathrm{~nm}$ emission) (Roche) was used for detection of nuclei. Briefly, cells were incubated for 60 minutes with phalloidin (diluted $1: 50$ by volume) at room temperature followed by an incubation with $1 \mu \mathrm{g} / \mathrm{ml}$ DAPI for $5 \mathrm{~min}$. Mineralization of the $45 \mathrm{~S} 5 \mathrm{nBG}$ in all cell culture samples was visualized by sample staining using the Osteolmage ${ }^{\mathrm{TM}}$ Mineralization Assay (Lonza, Germany), where the stock solution was diluted 1:100 (v/v) and then subsequently incubated for 30 minutes at room temperature. Samples were washed and stored in 1x PBS until microscopic imaging. 3D confocal microscopic images were obtained and computer processed (Amira 3D Software for Life Sciences, FEI, USA) to build 3D schematic images.

2.6 Scanning electron microscopy: After 14 days the interaction of $\mathrm{nBG}$ with the cell membrane of cultured RAW cells was characterized using scanning electron microscopy (SEM): (Auriga CrossBeam, Carl Zeiss Microscopy GmbH, Germany). Briefly, cells were detached by a cell scraper and the remaining samples were directly collected and centrifuged using $200 \mathrm{~g}$. Afterwards, the supernatant was removed and the cell pellet was fixed in 3 vol.\% paraformaldehyde, 3 vol.\% glutaraldehyde (Sigma-Aldrich, Germany) and 0.2 M sodiumcacodylate (Sigma-Aldrich, Germany). After dehydration through incubation with a series of graded ethanol series $(30,50,70,80,90,95$ and 100 vol.\%), the samples were critical point dried with $\mathrm{CO}_{2}$ (EM CPD300, Leica, Germany) and imaged without sputtering.

\subsection{Statistics:}

Data are presented as means \pm SEM. All results were analyzed using the non-parametric Mann-Whitney-U test for independent samples. Statistical significance was set at $P<0.05=$ ${ }^{*}$ and $\mathrm{P}<0.005={ }^{* *}$. All statistical tests were processed using SPSS 21 (IBM, New York, USA). 


\section{Results}

\section{1 $45 S 5 n B G$ promotes rapid cell interaction and adherence of RAW 264.7 cells.}

In order to determine the influence of $45 S 5 \mathrm{nBG}$ on cellular morphology we cultured RAW 264.7 cells for 14 days in DM with a range of $45 S 5 \mathrm{nBG}$ concentrations $(0.1 \mu \mathrm{g} / \mathrm{ml}-1000$ $\mu \mathrm{g} / \mathrm{ml}$ ) (Fig.1A). Following cell seeding, lower $45 \mathrm{~S} 5 \mathrm{nBG}$ concentrations $(0.1-100 \mu \mathrm{g} / \mathrm{ml})$ revealed that RAW 264.7 cells were morphologically similar to cells seeded on the reference, where they were rounded in appearance with only a few cells attached (Fig. 1A). In contrast, for cells seeded in the presence of $500 \mu \mathrm{g} / \mathrm{ml}$ or $1000 \mu \mathrm{g} / \mathrm{ml} 45 S 5 \mathrm{nBG}$, we observed larger cell clusters which appeared well attached to the surface, supporting that $45 \mathrm{~S} 5 \mathrm{nBG}$ at a higher concentration facilitates a rapid recovery time for cellular interaction and attachment (Fig.1A and data not shown). After 14 days of growth, the cells demonstrated many round cellular clusters and the presence of multinucleated cells for all $45 \mathrm{~S} 5 \mathrm{nBG}$ concentrations $(0.1 \mu \mathrm{g} / \mathrm{ml}-500 \mu \mathrm{g} / \mathrm{ml})$.

\section{2 $45 S 5 n B G$ promotes high viability and proliferation of RAW 264.7 cells.}

Addressing both the cellular proliferation and viability after 14 days of growth we observed that RAW 264.7 cells showed high proliferation ( $10-15 \%$ above the reference; $120 \%)$ with a viability of $\sim 80 \%$ between $0.1 \mu \mathrm{g} / \mathrm{ml}-100 \mu \mathrm{g} / \mathrm{ml} 45 \mathrm{~S} 5 \mathrm{nBG}$ (Fig. 1B). Although cell viability was high when RAW 264.7 cells were grown in the presence of $500 \mu \mathrm{g} / \mathrm{ml} \mathrm{nBG}$, the cell proliferation halted, supporting a shift in phenotype of monocyte-macrophage cells to terminally differentiated osteoclasts (Fig. 1B). Importantly, at nBG concentrations of 1000 $\mu \mathrm{g} / \mathrm{ml}$ cell viability and proliferation significantly dropped below $10 \%$ along with an increase of $\mathrm{pH}$ to 9.8 , thus this concentration resulted in cellular toxicity after 14 days of cultivation. As can be seen in the LM-images (Suppl. Fig. 1), $1000 \mu \mathrm{g} / \mathrm{ml}$ of $\mathrm{nBG}$ on stimulated RAW cells showed no cytotoxic effect after 6 days of incubation, but afterwards more and more cells showed necrotic injuries. We further determined that the $\mathrm{LC}_{50}$ value for $45 \mathrm{~S} 5 \mathrm{nBG}$ was approximately $790 \mu \mathrm{g} / \mathrm{ml}$ (data not shown). For additional experiments described below, although we examined all 45S5 nBG concentrations, we mainly focused on the influence of the $500 \mu \mathrm{g} / \mathrm{ml}$ concentration correlating with the terminally differentiated state of osteoclasts.

\subsection{Gene expression of specific genes is linked with osteoclast differentiation and vascularization.}

Because expression of marker genes correlates with osteoclast differentiation, we examined the expression of Cd14, Rankl, Trap5a/b, Ca2, Cathepsin k (Ctsk), Vegfa and Ror2 in RAW 264.7 cells with increasing concentrations of $\mathrm{nBG}$ in DM. Importantly, the mouse endogenous retroviral (ERV) envelope genes Syncytin- $A$ and Syncytin- $B$, functional 
orthologues to the human cell fusogenic envelope genes, ERVW-1 and ERVFRD-1 called Syncytin-1 and Syncytin-2 were also analyzed. Syncytin-A and Syncytin-B were identified at the mouse placental syncytiotrophoblast layer, which is formed early in development following multiple cell fusions of trophoblast progenitor cells [22].

Results showed that when cells were grown in DM, five genes, namely Ctsk, Ca2, Vegf-a, Trap5a/b and Cd14 were significantly increased in expression at $500 \mu \mathrm{g} / \mathrm{ml} 45 \mathrm{~S} 5 \mathrm{nBG}$ (Fig. 2). These results demonstrated that RAW 264.7 cells clearly express genes associated with osteoclast differentiation but also still express the monocyte surface marker $C d 14$. Interestingly, at lower concentrations of $\mathrm{nBG}$ (between $0.05-5.0 \mu \mathrm{g} / \mathrm{ml}$ ) a significant expression of Rankl was observed, thus these cells most likely secrete this protein contributing to autocrine regulation and differentiation. Additionally, Ror2, Syncytin-A and Syncytin-B demonstrated significant increases of expression at lower $45 \mathrm{~S} 5 \mathrm{nBG}$ concentrations $(0.5-5.0 \mu \mathrm{g} / \mathrm{ml})$, supporting that commitment and initiation of cell fusion occur early.

3.4 45S5 nBG promotes differentiation of RAW 264.7 TRAP positive expressing osteoclastlike cells.

To test the influence of $45 \mathrm{~S} 5 \mathrm{nBG}$ concentrations on osteoclast differentiation of RAW 264.7 cells we assayed for TRAP positive cells after 14 days of growth. Although the mean cellular size remained constant $(\sim 20 \mu \mathrm{m})$ when cells were cultured with increasing concentrations of $45 S 5$ nBG in culture media without growth factors, an increase in the number of TRAP positive single cells was observed above $100 \mu \mathrm{g} / \mathrm{ml}$ 45S5 nBG (data not shown). This finding supports that in the presence of higher concentrations of $45 \mathrm{~S} 5 \mathrm{nBG}$, RAW 264.7 cells become stimulated to produce TRAP but without formation of multi-nucleated osteoclast cells. On the other hand, when cells were grown for 14 days with M-CSF and RANKL we observed TRAP induction in both single and multinucleated cells with a mean cell size which increased from $\sim 40 \mu \mathrm{m}$ to $55 \mu \mathrm{m}$ (mean $=38 \mu \mathrm{m}$ ) in agreement with low to high $45 \mathrm{~S} 5 \mathrm{nBG}$ concentrations (Fig. 3).

3.5 Detection of multi-nucleated RAW 264.7 cells and mineral complexes of calcium phosphate / $45 S 5$ nBG using fluorescence microscopy.

To further confirm the presence of multi-nucleated cells we analyzed RAW 264.7 cells cultured with different concentrations of $45 S 5$ nBG using fluorescence microscopy. Results not only confirmed the presence of multi-nucleated osteoclast cells but also formation of the classic 'actin ring' (Fig. 4). For example, we observed an increase of mean cell size (55 $\mu \mathrm{m})$ and the presence of multi-nucleated cells with a prominent 'actin ring' when RAW 264.7 cells 
were cultured with $500 \mu \mathrm{g} / \mathrm{ml} 45 \mathrm{~S} 5 \mathrm{nBG}$ (Fig. 4A). In parallel, we localized $\mathrm{Ca}^{2+}$ and $\mathrm{PO}_{4}{ }^{3-}$ ions associated with $\mathrm{nBG}$ in cell cultures after 14 days of growth and with increasing $\mathrm{nBG}$ concentrations (Fig. 4A). Using fluorescence microscopy we found calcium phosphate particles specifically associated with phalloidin stained cells throughout the cell culture. During the cultivation period of 14 days $\mathrm{nBG}$ sedimented on the bottom of the cell culture dish next to the adherent grown osteoclast-like cells. To examine these clusters in more detail confocal microscopy (Fig 4B-C) showed that clusters of calcium phosphate and nBG were associated together and with the cell membrane (below and on top). Therefore, our results demonstrate that RAW 264.7 cells associate specifically with calcium phosphate / nBG complexes.

\subsection{Detection of cell surface $n B G /$ mineral complexes using scanning electron microscopy} (SEM).

To further confirm the association of nBG/mineral complexes with RAW 264.7 cells we performed SEM analyses at day 14 of cell growth in DM (Fig 5 A,B). Imaging results showed, following centrifugation of cells, no detection of mineral complexes associated with $\mathrm{nBG}$, whilst cells were found in the overview (Fig.5 A). In contrast, imaging cells at higher magnification showed prominent mineral complexes associated with $\mathrm{nBG}$ and cells.

\section{Discussion}

The process of bone homeostasis and bone remodeling occurs throughout the life of higher vertebrates and in mammals. In order to maintain a critical skeletal mass there is a delicate balance between bone resorption and synthesis [23,24]. This is achieved by specialized terminally differentiated hematopoetic cells, namely osteoclasts and osteoblasts, respectively, where cross talk via growth factors and cytokines (e.g. interleukins-1and -6) is prominent between both cell types [2]. In particular, following cytokine secretion from osteoblast lineage cells [e.g. macrophage colony stimulating factor (M-CSF), receptor activator of the NF-KB ligand (RANK-L)], stimulation of bone marrow monocytic progenitors differentiate into osteoclasts with bone-resorbing activities [2]. Whereas RANKL stimulates several aspects of osteoclast function, OPG (osteoprotegerin) blocks RANKL, and inhibits bone resorption [25]. In in vitro studies, differentiation of different cell types into functioning osteoclast-like cells has been reported to occur upon cytokine stimulation [26-28]. Bioactive glasses are important biomaterials for bone tissue regeneration due to their bioactivity and osteoconductivity [15, 16, 27]. Since the discovery of 45S5 BG in 1971 there have been over one million patients who have received this bone substitute for surgery $[15,28]$. More recently, the advantages of $45 S 5$ BG for use as scaffold materials for tissue engineering have been investigated including biodegradation, increased apatite formation, promotion of 
osteo and angiogenic properties and the establishment of chemical bonds with the surrounding bone tissue [27, 28, 29]. Nanoparticles or granules for clinical use have the advantage that they can be easily pushed and formed into a bone defect. nBG of nominal $45 S 5$ composition (available since 2006 [18]) has not been extensively tested using in vitro cell culture studies. Granules, especially nanoparticles, for clinical use applied in a gel or paste can be easily pushed and formed into a bone defect while maintaining its advantage of a high reactivity". The beneficial application of nBG incorporated in a covalently crosslinked alginate dialdehyde-gelatin hydrogel matrix is shown already in vitro and in vivo by Rottensteiner et al.[31]. Beside pastes and putties use, these hybrid systems are also promising approaches for additive manufacturing of biomedical implants and even for biofabrication [32,33].

Our present investigation for the first time brings forth biological and physical information regarding the influence that different $\mathrm{nBG}$ concentrations have on cell viability, proliferation, differentiation and gene expression using RAW 264.7 monocyte-macrophage cells, which can be stimulated to differentiate into osteoclast-like cells. Interestingly, when human peripheral mononuclear cells (hPBMNC) stimulated with M-CSF and RANKL in the contact with different nBG concentrations for 14 days, they indicated higher cell activities, but similar cell behavior like the RAW 264.7 cells. This is illustrated in the supplementary data, where cell proliferation and vitality, TRAP staining and actin ring formation are shown (Suppl. Fig. 2 A-C).

Previous publications using different silica-based nanoparticles incubated with different cell types have demonstrated both positive and negative biological outcomes based on their physical properties. For example, one study using $50 \mathrm{~nm}$ silica nanoparticles containing cobalt and a surface modification with polyethylene glycol demonstrated potent inhibitory effects on osteoclasts, but on the other hand a stimulatory effect on osteoblasts in vitro, and furthermore increased bone density in vivo in mice [34]. Even the presence of Si in culture media with nanosized silica and the RAW 264.7 murine monocytic - macrophage cell line was shown to inhibit bone resorption [35]. In another study, using sol-gel methodology, $100 \mathrm{~nm}$ nBG particles $\left(\mathrm{SiO}_{2}-\mathrm{CaO}-\mathrm{P}_{2} \mathrm{O}_{5}\right)$ of atomic ratios of Si:Ca:O:P (28:24:40:2.6) increased calcium deposition over 14 days when cultured with mouse pre-osteoblastic cell line MC3T3-E1 [36]. In the same study different concentrations of nBG particles demonstrated that $100 \mu \mathrm{g} / \mathrm{ml}$ stimulated proliferation but $500-1000 \mu \mathrm{g} / \mathrm{ml}$ concentrations reduced viability of primary rat osteoprogenitor cells cultured for $24 \mathrm{hrs}$. Furthermore, using sol-gel methodology sub-micron bioactive glass particles $\left(85 \% \mathrm{SiO}_{2}, 15 \% \mathrm{CaO}\right)$ with a mean particle size of $250 \mathrm{~nm}$ demonstrated significant HAp formation in simulated body fluid (SBF) after five days and no cytotoxicity with human mesenchymal stem cells (h-MSC); however 
after 7 days a reduction in cell viability occurred [37]. A comparative study demonstrated that nBG particles of various sizes $(40-1000 \mathrm{~nm})$ and composition $60 \% \mathrm{SiO}_{2}, 36 \% \mathrm{CaO}$, and $4 \%$ $\mathrm{P}_{2} \mathrm{O}_{5}$ supported cell adherence and growth with all particle dimensions [38]. These studies point to the importance of the chemical composition of bioactive glasses, but also to the relevance of nanoparticle size in affecting the regulation of bone cells.

We previously performed a methodical approach to investigate the structure and bioreactivity kinetics of $45 \mathrm{~S} 5 \mathrm{nBG}$ in SBF [19]. Additionally we tested the effect of nBG on cytotoxicity using the human osteocarcinoma cell line (MG-63), which exhibits osteoblast-like behavior [19]. Not only did $\mathrm{nBG}$ promote fast formation of $\mathrm{HAp}$ along with $\mathrm{CaCO}_{3}$ crystal growth within 1 day, but we hypothesized that the increased reactivity was due to the nonuniform structure and relatively higher surface area of $n B G$ as shown by transmission electron microscopy, X-ray diffraction and Fourier transform infrared (FT-IR) spectroscopy [19]. Importantly, exposing MG-63 cells to $0.1-200 \mu \mathrm{g} / \mathrm{ml} \mathrm{nBG}$ increased the proliferative growth even at the highest concentration of $1000 \mu \mathrm{g} / \mathrm{ml}$ after $48 \mathrm{hr}$ [19]. In this present investigation we used the same $45 \mathrm{~S} 5 \mathrm{nBG}$ particles as in ref [17], but we tested them for osteoclast differentiation. Considering RAW 264.7 monocyte-macrophage cells we also found increased viability ( $80 \%)$ at lower $45 \mathrm{~S} 5 \mathrm{nBG}$ concentrations, which increased at 500 $\mu \mathrm{g} / \mathrm{ml}$ (100\% viability) following 14 days of growth in the presence of M-CSF and RANKL. One indicator for a terminally differentiated cell is reduced DNA synthesis, thus our findings of high viability along with significantly reduced DNA synthesis at $500 \mu \mathrm{g} / \mathrm{ml} 45 \mathrm{~S} 5 \mathrm{nBG}$ supports that at this concentration osteoclasts are fully differentiated. Interestingly, in a coculture system of human osteogenic sarcoma cells (SaOs-2) and mouse monocytes (RAW 264.7) it was shown that $10 \mathrm{mM}$ silicate enhances the growth of osteoblasts, while the osteoclastic differentiation of RAW 264.7 cells was strongly decreased [39]. However, as Schröder et al. stated in this study, the inhibition of RAW 264.7 cell differentiation cells might due to increased levels of OPG, which were synthesized by human osteogenic sarcoma cells (SaOS-2) after exposure to silicate. Similar results were shown by Jiao et al. [36], who presented an up-regulated OPG expression and a down-regulated RANKL expression in mesenchymal stem cells cultured on collagen scaffolds containing silica and apatite, resulting in inhibition of the differentiation of RAW 264.7 cells. Summarizing these studies, it seems that regarding bone remodeling, silica based materials in a concentration dependent manner can inhibit the osteoclast activity indirectly by the stimulation of OPG expression in osteoblasts. Support for differentiation of osteoclasts stems from our findings of higher numbers of TRAP5 stained positive cells along with increased amounts of multinucleated cells with a mean diameter of $55 \mu \mathrm{m}$ and prominent 'actin rings'. It is interesting to note that when cells were grown in the absence of cytokines we observed an increase of TRAP5 positive stained cells, but with no significant osteoclast differentiation. This finding indicated 
that the $45 \mathrm{~S} 5 \mathrm{nBG}$ particles alone can activate induction of TRAP gene expression, however cytokines are needed to induce pre-osteoclast differentiation into multinucleated cells. This finding is corroborated by our results of TRAP5 gene expression levels steadily increasing in the presence of $10 \mu \mathrm{g} / \mathrm{ml}$ up to $500 \mu \mathrm{g} / \mathrm{ml} \mathrm{nBG}$ with or without M-CSF and RANKL. It has also been reported in the literature that bio-polyphosphate induced gene expression of the BMP gene in the human osteogenic sarcoma (SaOS-2) cell line [40]. Furthermore, induction of genes involved in transcriptional regulation, signal transduction, growth factors and cytokines were observed in primary human osteoblasts exposed to ionic dissolution products of $B G[41,42]$.

There are many critical genes and protein signalling promoting osteoclastogenesis in a step wise manner; 1) PU.1 transcription factor which initiates commitment of progenitor cells; 2) pre-osteoclast differentiation via Wnt5a / Ror2, activation of RANKL signaling with transcription factors NFKB, AP-1 and increased levels of nuclear factor of activated $\mathrm{T}$ cell cytoplasmic 1 (NFATc1); 3) commencement of osteoclast bone resorption; TRAP5, cathepsin K, carbonic anhydrase II and VEGF (also essential for angiogenesis) [43-48]. Our present gene expression analysis not only demonstrates RAW 264.7 monocyte-macrophage cell gene expression of many of these critical genes above, but interestingly, supports the idea that osteoclast genes are regulated by different concentrations of $45 \mathrm{~S} 5 \mathrm{nBG}$. For example, both Ror-2 and Rankl gene expression levels induced with a 5-fold induction at 10 $\mu \mathrm{g} / \mathrm{ml}$, but then steadily decreased at higher nBG concentrations, supporting autocrine regulation and osteoclast commitment of RAW 264.7 cells. In line with commitment, the mouse developmental genes Syncytin- $A$ and Syncytin- $B$, essential for cell fusion of trophoblast progenitors to the multinucleated syncytiotrophoblast [22], were significantly induced in expression around the same nBG concentration as Rankl. Interestingly, human Syncytin-1 was previously shown to mediate cell fusions of pre-osteoclasts to osteoclasts by RNA, protein expression studies and in vitro using a Syncytin-1 peptide which inhibited osteoclast differentiation [49]. Therefore, it is conceivable that Syncytin- $A$ and Syncytin- $B$ could play a role in cell fusion during osteoclast differentiation in the mouse. Lastly, at concentrations above $100 \mu \mathrm{g} / \mathrm{ml}$ at $500 \mu \mathrm{g} / \mathrm{ml}$ differentiating osteoclasts showed a steep increase of gene expression of Ctsk, Car-2, Trap5 and Vegfa, supporting that terminally differentiated osteoclasts have bone resorbing activity, but additionally could be a trigger for angiogenesis. It is interesting to note that in another study secretion of VEGF by human fibroblast cells appeared to be dependent on particle size and concentration of a different bioactive glass (BG S53P4) [50]. Indeed the angiogenic effect 45S5 BG has been reported by several authors, as reviewed by Gorustovich et al [30]. Furthermore, our results demonstrating that clusters of calcium phosphate with nBG specifically associated with the 
cellular membrane supports that the presence of intercellular nBG could be a factor leading to gene activation and subsequent osteoclast differentiation.

\section{Conclusions}

We conclude that $45 \mathrm{~S} 5 \mathrm{nBG}$ promotes:

1) Rapid RAW 264.7 cell interaction, attachment, high viability and proliferation.

2) Differentiation of TRAP5 positive expressing osteoclast-like cells.

3) Differentiation into osteoclast-like multinucleated cells.

4) Regulation of osteoclast genes, which is dependent on $\mathrm{nBG}$ concentration.

5) Mineralization and direct association of $\mathrm{nBG}$ with cells.

Taken together, we further conclude that nBG enhances RAW 264.7 osteoclast differentiation especially by controlling gene expression in a concentration dependent manner, which could reflect normal regulation during bone growth and remodeling.

\section{Acknowledgements}

This project was supported by the Emerging Fields Initiative (EFI) of the University of Erlangen-Nuremberg (project TOPbiomat). The authors acknowledge A. Gruenewald for experimental assistance. 


\section{Literature}

1. Laurencin C, Khan Y, El-Amin SF. Bone graft substitutes. Expert Rev. Med. Devices. 3, 49-57 (2006).

2. Detsch $R$, Boccaccini AR. The role of osteoclasts in bone tissue engineering. J. Tissue Eng. Regen. Med. (2014).

3. Fratzl P, Weinkamer R. Nature's hierarchical materials. Prog. Mater. Sci. 52(8), 12631334 (2007).

4. Hollister SJ. Porous scaffold design for tissue engineering. Nat. Mater. 5(7), 590-590 (2006).

5. Hutmacher DW. Scaffolds in tissue engineering bone and cartilage. Biomaterials 21(24), 2529-2543 (2000).

6. Redey S a., Razzouk S, Rey C, et al. Osteoclast adhesion and activity on synthetic hydroxyapatite, carbonated hydroxyapatite, and natural calcium carbonate:

Relationship to surface energies. J. Biomed. Mater. Res. 45, 140-147 (1999).

7. Rezwan K, Chen QZ, Blaker JJ, Boccaccini AR. Biodegradable and bioactive porous polymer/inorganic composite scaffolds for bone tissue engineering. Biomaterials. 27, 3413-3431 (2006).

8. Dimitriou R, Tsiridis E, Giannoudis P V. Current concepts of molecular aspects of bone healing. Injury. 36(12), 1392-1404 (2005).

9. Detsch R, Hagmeyer D, Neumann $M$, et al. The resorption of nanocrystalline calcium phosphates by osteoclast-like cells. Acta Biomater. 6(8), 3223-33 (2010).

10. Wei S. Receptor Activator of Nuclear Factor- B Ligand Activates Nuclear Factor- B in Osteoclast Precursors. Endocrinology. 142, 1290-1295 (2001).

11. Mouline CC, Quincey D, Laugier JP, et al. Osteoclastic differentiation of mouse and human monocytes in a plasma clot/biphasic calcium phosphate microparticles composite. Eur. Cells Mater. . 20, 379-392 (2010).

12. Detsch R, Schaefer S, Deisinger U, Ziegler G, Seitz H, Leukers B. In vitro: osteoclastic activity studies on surfaces of 3D printed calcium phosphate scaffolds. J. Biomater. Appl. 26(3), 359-80 (2011).

13. Heinemann C, Heinemann S, Worch H, Hanke T. Development of an osteoblast/osteoclast co-culture derived by human bone marrow stromal cells and human monocytes for biomaterials testing. Eur. Cells Mater. 21, 80-93 (2011).

14. Jones GL, Motta A, Marshall MJ, EI Haj AJ, Cartmell SH. Osteoblast: Osteoclast cocultures on silk fibroin, chitosan and PLLA films. Biomaterials . 30(29), 5376-5384 (2009).

15. Bernhardt A, Schumacher M, Gelinsky M. Formation of Osteoclasts on Calcium Phosphate Bone Cements and Polystyrene Depends on Monocyte Isolation Conditions. Tissue Eng. Part C Methods 21(2), 160-170 (2015).

16. Keller J, Brink S, Busse B, et al. Divergent Resorbability and Effects on Osteoclast Formation of Commonly Used Bone Substitutes in a Human In Vitro-Assay. PLoS One . 7(10), e46757 (2012).

17. Hench LL. Bioceramics. J. Am. Ceram. Soc. 81(7), 1705-1727 (1998).

18. Erol-Taygun M, Zheng K, Boccaccini AR. Nanoscale Bioactive Glasses in Medical Applications. Int. J. Appl. Glas. Sci. 4(2), 136-148 (2013).

19. Mačković M, Hoppe A, Detsch R, et al. Bioactive glass (type 45S5) nanoparticles: in vitro reactivity on nanoscale and biocompatibility. J. Nanoparticle Res. 14(7), 966 (2012).

20. Brunner TJ, Grass RN, Stark WJ. Glass and bioglass nanopowders by flame synthesis. Chem. Commun. (Camb).1384-1386 (2006).

21. Strick R, Ackermann S, Langbein M, et al. Proliferation and cell-cell fusion of endometrial carcinoma are induced by the human endogenous retroviral Syncytin-1 and regulated by TGF-beta. J. Mol. Med. (Berl). 85(1), 23-38 (2007). 
22. Dupressoir A, Marceau G, Vernochet $C$, et al. Syncytin-A and syncytin-B, two fusogenic placenta-specific murine envelope genes of retroviral origin conserved in Muridae. Proc. Natl. Acad. Sci. U. S. A. 102(3), 725-30 (2005).

23. Harada S, Rodan GA. Control of osteoblast function and regulation of bone mass. Nature . 423(6937), 349-55 (2003).

24. McArdle A, Marecic O, Tevlin R, et al. The role and regulation of osteoclasts in normal bone homeostasis and in response to injury. Plast. Reconstr. Surg. 135(3), 808-16 (2015).

25. Boyle WJ, Simonet WS, Lacey DL. Osteoclast differentiation and activation. Nature 423(6937), 337-42 (2003).

26. Severson AR. Differentiation of mononuclear cells into multinucleated osteoclast-like cells. Exp. Cell Biol. 51, 267-274 (1983).

27. Detsch R, Mayr H, Ziegler G. Formation of osteoclast-like cells on HA and TCP ceramics. Acta Biomater. 4(1), 139-48 (2008).

28. Fong $\mathrm{D}$, Bisson M, Laberge $\mathrm{G}$, et al. Bone morphogenetic protein- 9 activates Smad and ERK pathways and supports human osteoclast function and survival in vitro. Cell. Signal. 25, 717-728 (2013).

29. Hench LL. The story of Bioglass?? J. Mater. Sci. Mater. Med. 17(11), 967-978 (2006).

30. Gorustovich AA, Roether JA, Boccaccini AR. Effect of bioactive glasses on angiogenesis: a review of in vitro and in vivo evidences. Tissue Eng. Part B. Rev. 16(2), 199-207 (2010).

31. Rottensteiner U, Sarker B, Heusinger D, et al. In vitro and in vivo Biocompatibility of Alginate Dialdehyde/Gelatin Hydrogels with and without Nanoscaled Bioactive Glass for Bone Tissue Engineering Applications. Materials (Basel). 7(3), 1957-1974 (2014).

32. Melchels FPW, Domingos M a N, Klein TJ, Malda J, Bartolo PJ, Hutmacher DW. Additive manufacturing of tissues and organs. Prog. Polym. Sci. 37(8), 1079-1104 (2012).

33. R. Gmeiner, U. Deisinger, J. Schönherr, B. Lechner, R. Detsch, A. R. Boccaccini, J. Stampfl et. al. Additive Manufacturing of Bioactive Glasses and Silicate Bioceramics. J. Ceram. Sci. Technol. 6(2), 75-86 (2015).

34. Beck GR, Ha S-WW, Camalier CE, et al. Bioactive silica-based nanoparticles stimulate bone-forming osteoblasts, suppress bone-resorbing osteoclasts, and enhance bone mineral density in vivo. Nanomedicine 8(6), 793-803 (2012).

35. Mladenović Ž, Johansson A, Willman B, Shahabi K, Björn E, Ransjö M. Soluble silica inhibits osteoclast formation and bone resorption in vitro. Acta Biomater. 10(1), 406418 (2014).

36. Moorthi a., Saravanan S, Srinivasan N, et al. Synthesis, Characterization and Biological Action of Nano-Bioglass Ceramic Particles for Bone Formation. J. Biomater. Tissue Eng. 2, 197-205 (2012).

37. Labbaf S, Tsigkou O, Müller KH, Stevens MM, Porter AE, Jones JR. Spherical bioactive glass particles and their interaction with human mesenchymal stem cells in vitro. Biomaterials 32(4), 1010-1018 (2011).

38. Lei B, Chen X, Han X, Zhou J. Versatile fabrication of nanoscale sol-gel bioactive glass particles for efficient bone tissue regeneration. J. Mater. Chem. 22(33), 16906 (2012).

39. Schröder HC, Wang $\mathrm{XH}$, Wiens $\mathrm{M}$, et al. Silicate modulates the cross-talk between osteoblasts (SaOS-2) and osteoclasts (RAW 264.7 cells): Inhibition of osteoclast growth and differentiation. J. Cell. Biochem. 113(10), 3197-3206 (2012).

40. Wiens $M$, Wang $X$, Schlossmacher $U$, et al. Osteogenic potential of biosilica on human osteoblast-like (SaOS-2) cells. Calcif. Tissue Int. 87(6), 513-24 (2010).

41. Xynos ID, Edgar AJ, Buttery LD, Hench LL, Polak JM. Gene-expression profiling of human osteoblasts following treatment with the ionic products of Bioglass $45 \mathrm{~S} 5$ dissolution. J. Biomed. Mater. Res. 55(2), 151-7 (2001).

42. Rahaman MN, Day DE, Sonny Bal B, et al. Bioactive glass in tissue engineering. Acta Biomater. 7(6), 2355-2373 (2011).

43. Rodan G a, Martin TJ. Therapeutic approaches to bone diseases. Science. 
289(September), 1508-1514 (2000).

44. Charles JF, Aliprantis AO. Osteoclasts: More than "bone eaters." Trends Mol. Med. 20(8), 449-459 (2014).

45. Wang X, Schröder HC, Wiens M, Ushijima H, Müller WEG. Bio-silica and biopolyphosphate: Applications in biomedicine (bone formation). Curr. Opin. Biotechnol. 23(4), 570-578 (2012).

46. Maeda K, Kobayashi Y, Udagawa N, et al. Wnt5a-Ror2 signaling between osteoblastlineage cells and osteoclast precursors enhances osteoclastogenesis. Nat. Med. 18(3), 405-12 (2012).

47. Nakagawa M, Kaneda T, Arakawa T, et al. Vascular endothelial growth factor (VEGF) directly enhances osteoclastic bone resorption and survival of mature osteoclasts. FEBS Lett. 473(2), 161-164 (2000).

48. Niida S, Kaku M, Amano H, et al. Vascular endothelial growth factor can substitute for macrophage colony-stimulating factor in the support of osteoclastic bone resorption. $J$. Exp. Med. 190(2), 293-298 (1999).

49. Søe K, Andersen TL, Hobolt-Pedersen AS, Bjerregaard Bolette B, Larsson LI, Delaissé JM. Involvement of human endogenous retroviral syncytin-1 in human osteoclast fusion. Bone. 48(4), 837-846 (2011).

50. Detsch R, Stoor P, Grünewald A, Roether JA, Lindfors NC, Boccaccini AR. Increase in VEGF secretion from human fibroblast cells by bioactive glass S53P4 to stimulate angiogenesis in bone. J. Biomed. Mater. Res. A 102(11), 4055-61 (2014). 

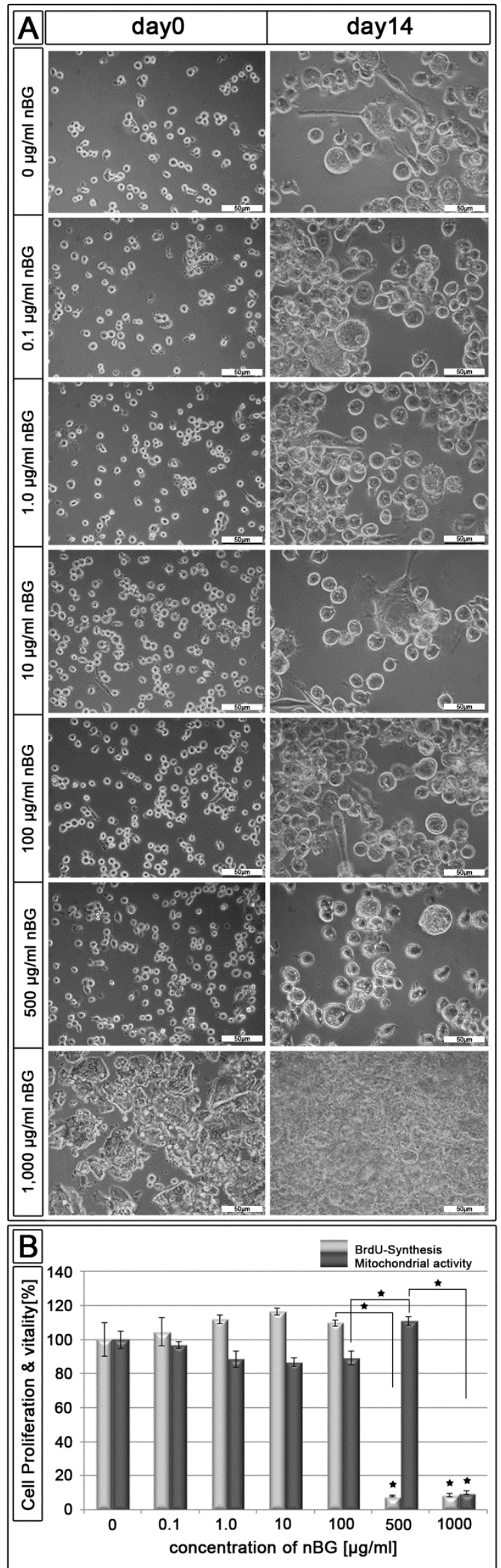
Figure 1 Cell morphology, proliferation and viability of RAW 264.7 cells after seeding and 14 days of culturing in DM with increasing concentrations of nBG. A. Concentration of $\mathrm{nBG}(0 \mu \mathrm{g} / \mathrm{ml}-1000 \mu \mathrm{g} / \mathrm{ml}$ correlates with a light microscopic morphological analyses of RAW cells at day 0 (left column, scale bare $=100 \mu \mathrm{m}$ ) and after day 14 (right column, (scale bare $=50 \mu \mathrm{m})$ of cultures with DM. Note that we observed cytotoxicity and increased $\mathrm{pH}$ levels $(\mathrm{pH} 9.8)$ at $1000 \mu \mathrm{g} / \mathrm{ml}$ with an $\mathrm{LC}_{50}$ value of approximately $790 \mu \mathrm{g} / \mathrm{ml}$. DM = differentiation media containing M-CSF and Rankl. B. Graph shows cell proliferation (\%) using BrdU Synthesis (black columns) and viability determined using mitochrondrial activity (\%) (grey striped columns) on y-axis of RAW 264.7 cells after 14 days with DM with increasing concentrations of $\mathrm{nBG}$ indicated on the $x$-axis. Statistically significant levels are indicated with * $p<0.05$ and ${ }^{* *} p<0.001$. 


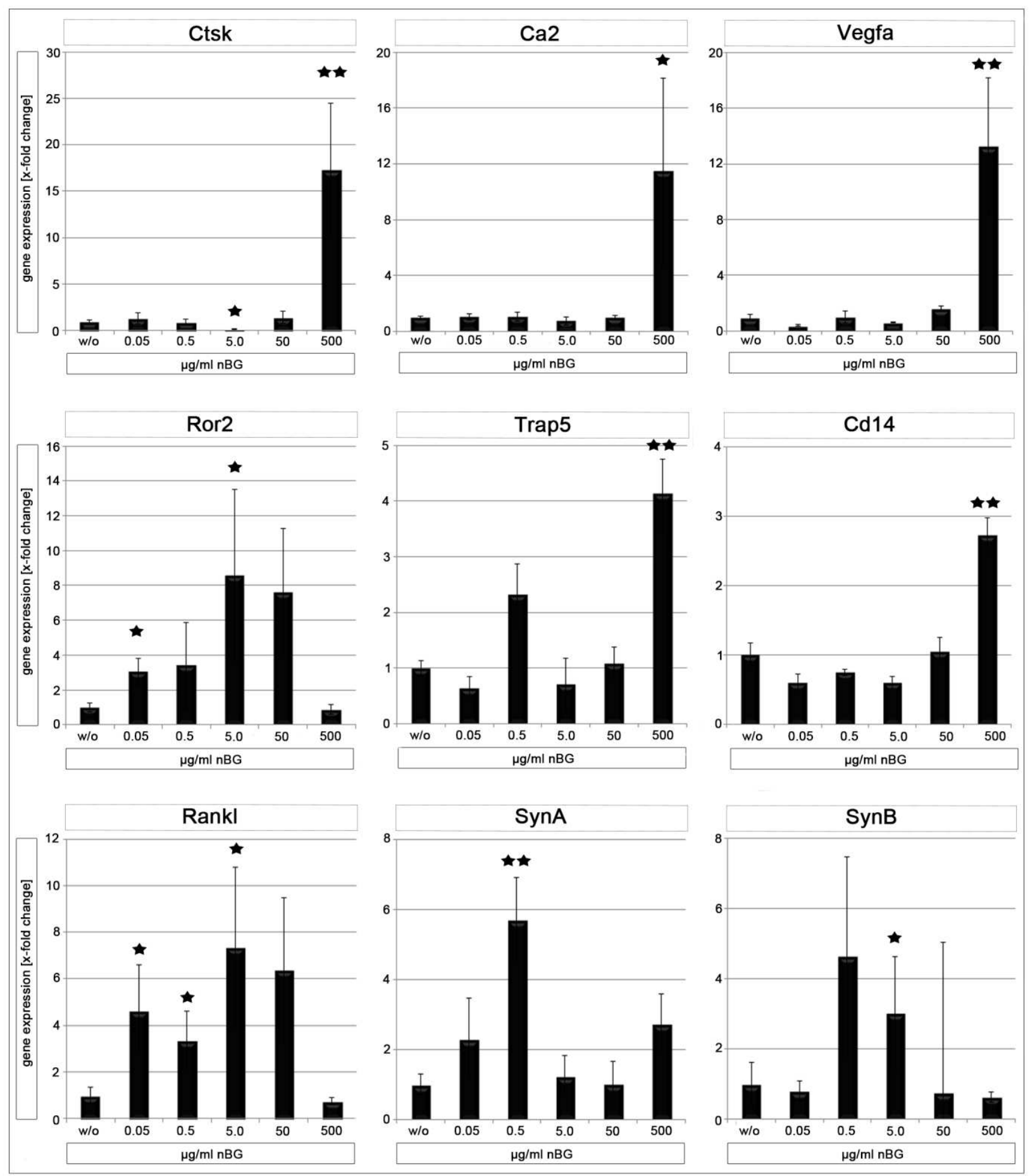




\begin{tabular}{|c|c|c|c|c|c|c|c|c|c|}
\hline & Ctsk & Rankl & Ror2 & Cd14 & Trap5 & $\mathrm{Ca} 2$ & Syna & Synb & Vegfa \\
\hline control & 1,00 & 1,00 & 1,00 & 1,00 & 1,00 & 1,00 & 1,00 & 1,00 & 1,00 \\
\hline sem & 0,176 & 0,365 & 0,254 & 0,175 & 0,132 & 0,113 & 0,288 & 0,601 & 0,203 \\
\hline sem & 0,568 & 1,957 & 0,760 & 0,118 & 0,205 & 0,237 & 1,169 & 0,275 & 0,058 \\
\hline p-value control DM & 0,964 & 0,027 & 0,007 & 0,185 & 0,368 & 0,837 & 0,591 & 0,250 & 0,109 \\
\hline $0,5 \mu \mathrm{g} / \mathrm{ml} \mathrm{nBG}$ & 0,95 & 3,34 & 3,41 & 0,75 & 2,31 & 1,06 & 5,68 & 4,62 & 1,02 \\
\hline p-value control DM & 0,497 & 0,012 & 0,545 & 0,677 & 0,005 & 0,428 & 0,001 & 0,093 & 0,968 \\
\hline $5 \mu \mathrm{g} / \mathrm{ml} \mathrm{nBG}$ & 0,17 & 7,32 & 8,54 & 0,60 & 0,71 & 0,75 & 1,23 & 3,02 & 0,62 \\
\hline sem & 0,059 & 3,470 & 4,971 & 0,090 & 0,478 & 0,306 & 0,598 & 1,593 & 0,020 \\
\hline p-value control DM & 0,009 & 0,011 & 0,005 & 0,164 & 0,368 & 0,498 & 0,659 & 0,048 & 0,768 \\
\hline $50 \mu \mathrm{g} / \mathrm{ml} \mathrm{nBG}$ & 1,47 & 6,36 & 7,57 & 1,05 & 1,09 & 1,00 & 1,02 & 0,76 & 1,62 \\
\hline p-value control DM & 0,000 & 0,968 & 0,840 & 0,000 & 0,000 & 0,029 & 0,152 & 0,208 & 0,000 \\
\hline
\end{tabular}

Figure 2. Gene expression analyses of RAW 264.7 cells after 14 days of culturing in DM with increasing concentrations of nBG. RNA was analyzed at day 14 from RAW 264.7 cells grown in DM with increasing concentrations of nBG. Gene expression was analysed for nine different genes involved in cellular fusion, osteoclast commitment and differentiation. Graphs show gene name indicated above; Y-axis represents gene expression in fold increase over control (without $\mathrm{nBG}$ ) set to 1 ; $\mathrm{x}$-axis represents bar graphs of mean gene expression levels from 4 independent experiments (sem indicated) at each concentration of $\mathrm{nBG}(\mu \mathrm{g} / \mathrm{ml})$. Statistically significant gene expression levels are indicated with * $p<0.05$ and ${ }^{* *} p<0.001$. Table below shows gene name with fold increase gene expression values with control set to 1 , sem values and $p$-values. $\mathrm{DM}=$ differentiation media containing M-CSF and Rankl. 


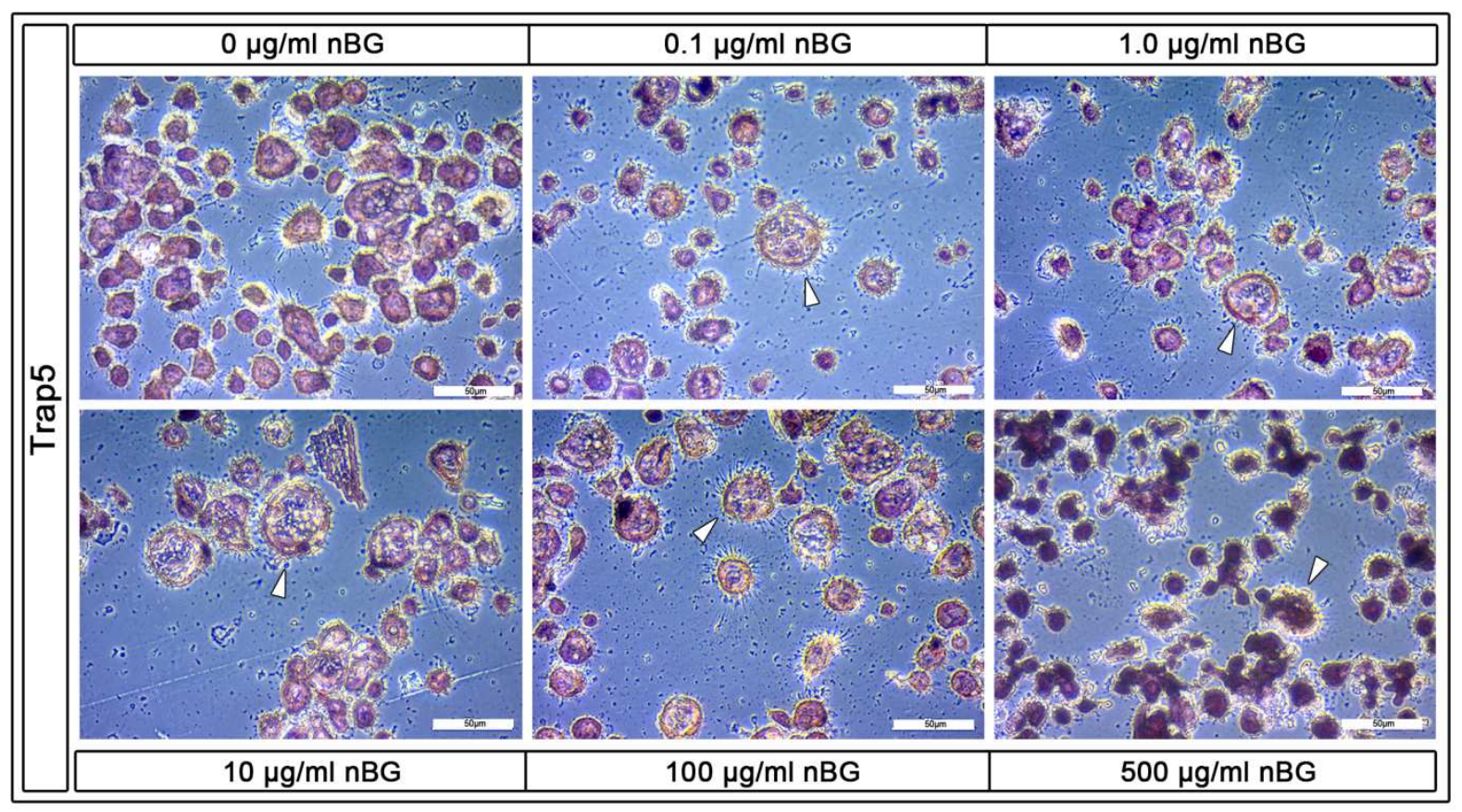

Figure 3. Analyses of Trap5 protein expression of RAW 264.7 cells after 14 days of culturing in DM with increasing concentrations of nBG. Top and bottom row of microscopic pictures showing Trap5 cellular staining correlates with increasing concentrations of $\mathrm{nBG} 0 \mu \mathrm{g} / \mathrm{ml}-1000 \mu \mathrm{g} / \mathrm{ml}$. Arrows show Trap5 positive multinucleated cells (scale bare $=50 \mu \mathrm{m})$. 

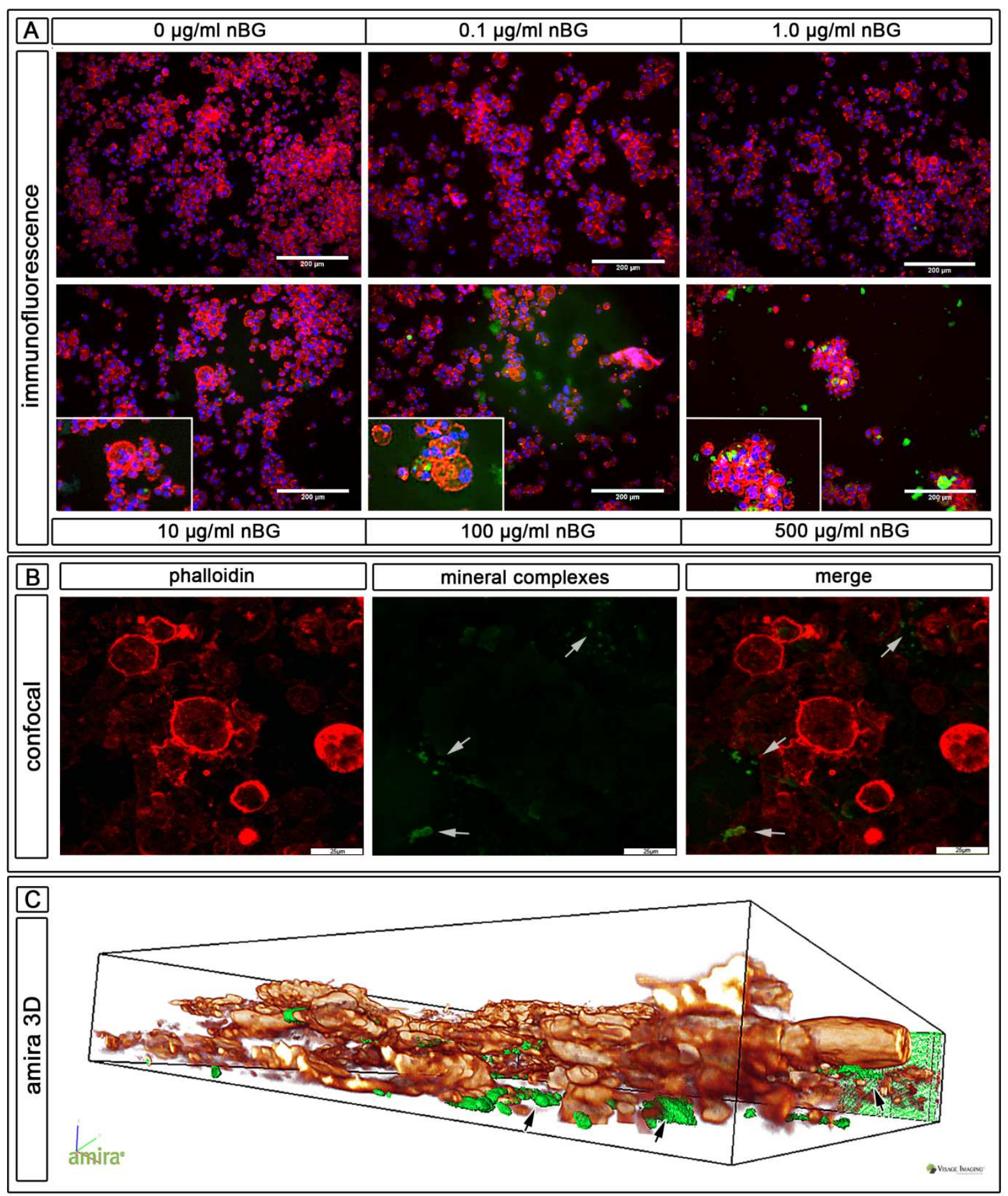

Figure 4. Analyses of actin intermediate filaments of RAW 264.7 cells and increased mineralization after 14 days of culturing in DM with increasing concentrations of $n B G$.

A. Top and bottom row of fluorescent microscopic pictures (scale bare $=200 \mu \mathrm{m}$ ) show RAW 264.7 cells staining positive for actin filaments (red phalloidin dye) and nuclear detection (DAPI) and detection of mineral complexes throughout the cell culture. Pictures correlate with increasing concentrations of $\mathrm{nBG}(0 \mu \mathrm{g} / \mathrm{ml}-500 \mu \mathrm{g} / \mathrm{ml})$. Examples show positive multinucleated 
cells with the classic actin ring and mineral complexes (green). Inset pictures represent magnified regions. B. Confocal microscopy showing actin ring and mineral complexes of RAW 264.7 cells and increased mineralization after 14 days of culturing in DM at $500 \mu \mathrm{g} / \mathrm{ml}$ of $\mathrm{nBG}$ (scale bare $=25 \mu \mathrm{m}$ ). A single representative confocal scan is shown demonstrating the actin rings (phalloidin dye, $B$ left), mineral complexes (green, $B$ center) and merged (B right). C. 3D picture (Amira) based upon a confocal stack of images with a step size of $1.01 \mu \mathrm{m}$ and a distance of $76.54 \mu \mathrm{m}$. Note the association of mineral complexes with the cell membrane and also encapsulated within the cell cytoplasm. 


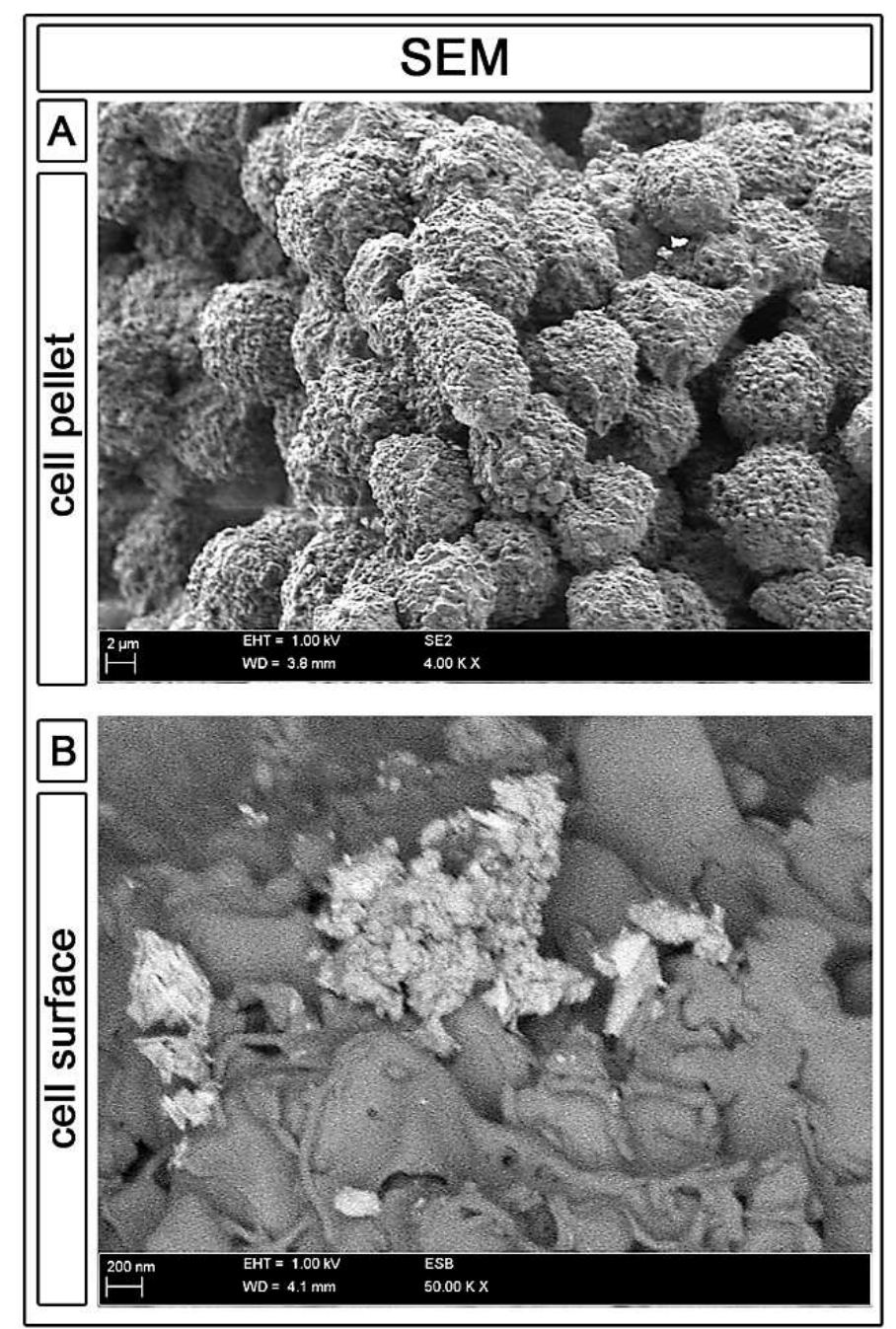

Figure 5. SEM images of RAW 264.7 cells and increased mineralization after 14 days of culturing in DM at $500 \mu \mathrm{g} / \mathrm{ml}$ of $\mathbf{n B G}$. Top picture shows the cell pellet using SEM at day 14 and the bottom picture shows SEM analyses of the cell surfaces (grey) and associated mineral complexes (light grey/white). 
Supplementary data 1

Table 1: Primers

\begin{tabular}{|c|c|c|}
\hline Name & TF for qPCR $\left(5^{‘} \rightarrow 3^{`}\right)$ & BR for qPCR $\left(5^{\prime} \rightarrow 3^{\prime}\right)$ \\
\hline 18srRNA & ATGGCCCTTAGTTGGTG & GAACGCCACTTGTCCCTCTA \\
\hline Syncytin-A* & GATGACATCCACTGCCACAC & ATTGTCCGGCTCGAATAGG \\
\hline Syncytin-B* & TTACCATGTCAGTGAACCCTACC & CGTTCTCCCAGACTGAATATTGT \\
\hline mCD14 & CAAGGTACTGAGTATTGCCCAAG & TCAGACAGGTCTAAGGTGGAGAG \\
\hline mRankl & TCCCATAAAGTCACTCTGTCCTC & AAGCCATCTTGGTTAACCCTTAG \\
\hline mCathepsin-K & AATCTTGTGGACTGTGTGACTGA & CATCTTCAGAGTCA \\
\hline mTrap5 & GTCTCTGCACAGATTGCATACTCTA & CCACAGTTATGTTTGTACGTGGA \\
\hline mRor-2 & ATGATTGAATGCTGGAATGAGTT & AGGTCTGCGCGGAACTATTAT \\
\hline mCar2 & GAAGCACTGCATTCCATTAAAAC & CAGGGTATGTCCAGTAGTCCAAG \\
\hline mVegfa & AGAAAGCATTTGTTTGTCCAAGAT & ATCTGCAAGTACGTTCGTTTAACTC \\
\hline
\end{tabular}

Trap5= tartrate resistant acid phosphatase 5

Ror-2 = receptor tyrosine kinase-like orphan receptor 2

Car2= carbonic anhydrase 2

Vegfa= vascular endothelial growth factor $A$

* Syncytin-A, Syncytin-B and 18srRNA primer according to Henke et al. 2013.

Supplementary data 2

Light microscopic images of RAW 264.7 cells incubated with $1000 \mu \mathrm{g} / \mathrm{ml} \mathrm{nBG}$ were used to analyse the cytotoxic effect of high nBG concentration on monocytes.

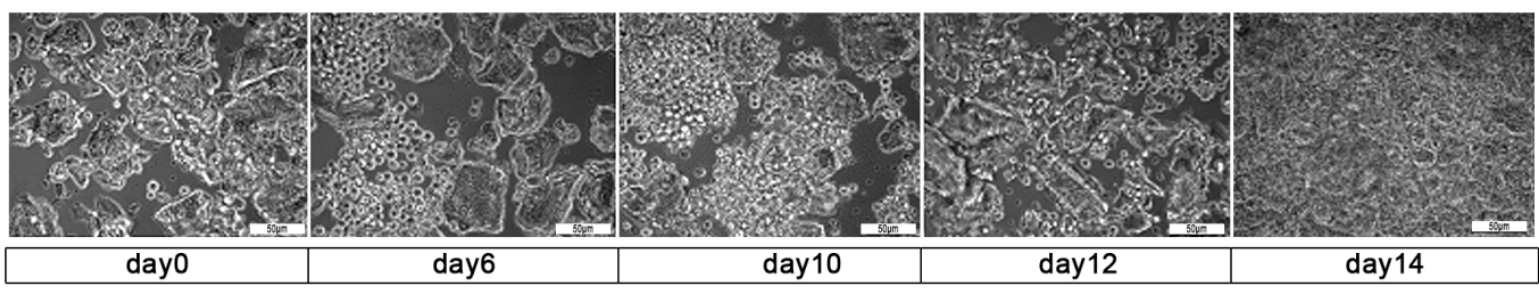

Supplement-Fig. 1: LM-images of stimulated RAW cells in contact with $1000 \mu \mathrm{g} / \mathrm{ml}$ after seeding, after $6 \mathrm{~d}, 10 \mathrm{~d}, 12$ and 14 days. (images from day 0 and 14 taken from Fig. 1A)

Supplementary data 3: human PBMNC incubated with nBG for 14d

For additional experiments human peripheral mononuclear cells (hPBMNC) were isolated by Ficoll-Paque sedimentation from volunteers (ethical permission from the University-Clinic Erlangen: 139 14B, 06.05.2014) and incubated in alpha-minimal essential medium with 10 vol. $\%$ fetal calf serum and with a range of $45 S 5 \mathrm{nBG}$ concentrations $(0.1 \mu \mathrm{g} / \mathrm{ml}-1000 \mu \mathrm{g} / \mathrm{ml})$ for 14 days, stimulated with macrophage colony-stimulating factor (human M-CSF, $25 \mathrm{ng} / \mathrm{ml}$ ) and receptor activator of the NFkappaB ligand (human RANKL, $40 \mathrm{ng} / \mathrm{ml}$ ). The measurement 
(following chapter 2.3) of proliferation and viability after 14 days of growth hPBMNC showed higher proliferation compared to the reference $(100 \mu \mathrm{g} / \mathrm{ml})$ and high stimulation effects on cell viability (Supplement-Fig. 1A). Again importantly, at $n B G$ concentrations of $500 \mu \mathrm{g} / \mathrm{ml}$ cell proliferation significantly dropped below $40 \%$. TRAP-staining (following chapter 2.5 ) was used to identify the osteoclastic differentiation. Therefore, hPBMNC were analysed for 14 days in DM with a range of $45 \mathrm{~S} 5 \mathrm{nBG}$ concentrations $(0.1 \mu \mathrm{g} / \mathrm{ml}-500 \mu \mathrm{g} / \mathrm{ml})$ : TRAP positive cells were found on all samples (Supplement-Fig. 1B). Furthermore, fluorescent microscopic images (Supplement-Fig. 1C) show hPBMC staining positive for actin filaments (red phalloidin dye) and nuclear detection (green, Sytox). Examples show positive multinucleated cells (in max. 9 nuclei) with the classic actin ring formation. 


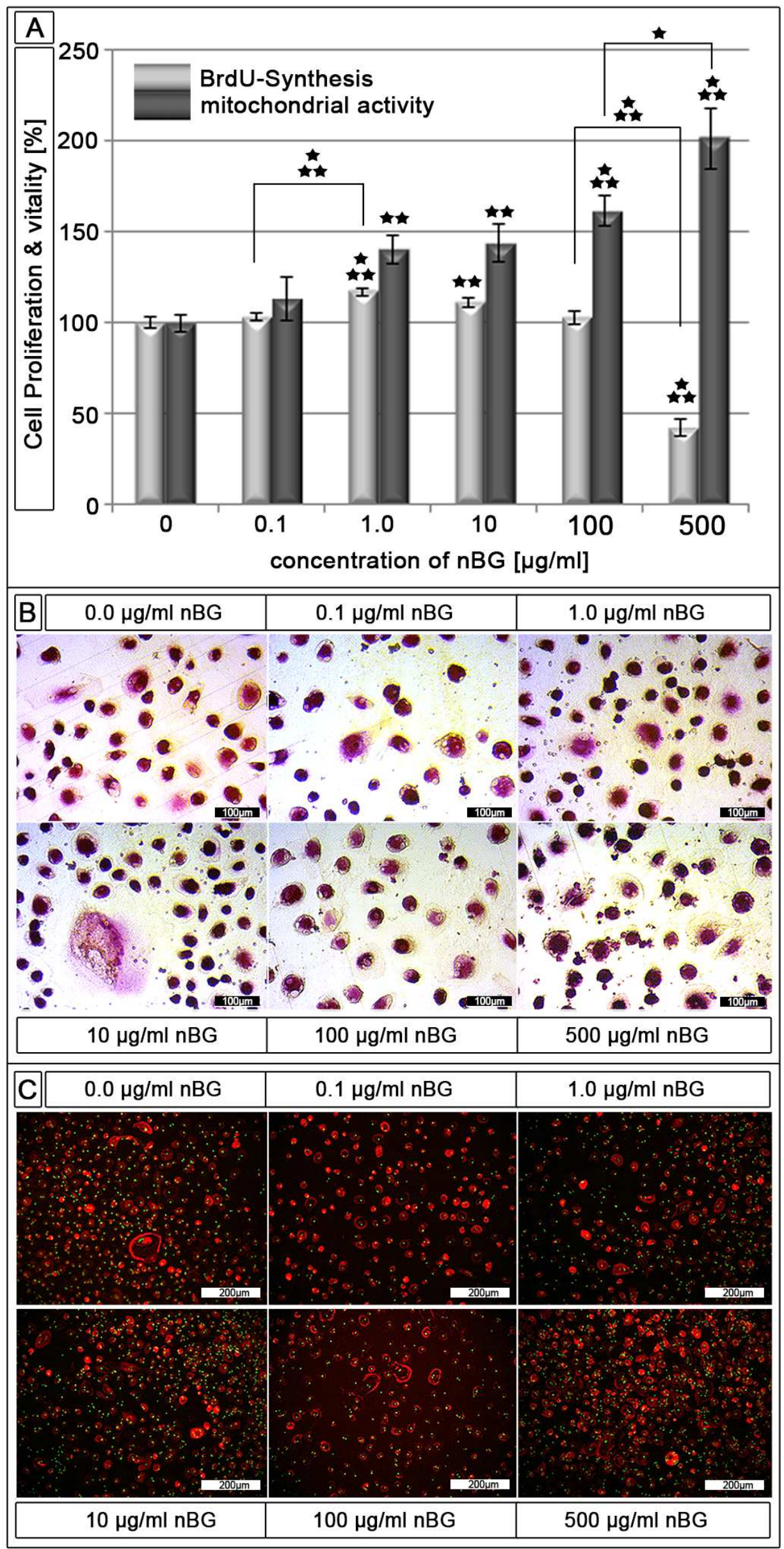


Supplement-Fig. 2 A: Cell proliferation and viability of hPBMNC after 14 days of culturing with increasing concentrations of nBG. Statistically significant levels are indicated with * $p<0.05$ and ${ }^{* *} p<0.001$. B: Analyses of Trap5 protein expression hPBMNC cells after 14 days of culturing with increasing concentrations of $\mathrm{nBG}$ (scale bare $=100 \mu \mathrm{m})$. C: Analyses of actin intermediate filaments of hPBMNC after 14 days of culturing with increasing concentrations of $\mathrm{nBG}$ (scale bare $=100 \mu \mathrm{m})$. 